\title{
THE PREPARATION AND COMPOSITION ANALYSIS OF ALITE-YE'ELIMITE WITH INDUSTRIAL WASTES
}

\author{
*YUEYANG HU, ${ }^{*}$ SUHUA MA*, WEIFENG LI*, XIAODONG SHEN*, ** \\ *College of Materials Science and Engineering, Nanjing Tech University, Nanjing 210009, China \\ **State Key Laboratory of Materials-Oriented Chemical Engineering, Room 111, \\ College of Materials Science and Engineering, Nanjing Tech University, \\ No. 5 Xinmofan Road, Gulou district, Nanjing, China \\ "E-mail: yc982@163.com
}

Submitted October 23, 2015; accepted March 10, 2016

\begin{abstract}
Keywords: Alumina modulus, Liquid properties, Alite, Calcium sulfoaluminate
Abstract: Alite-ye'elimite clinker is a high cementing clinker that is prepared by introducing calcium sulfoaluminate, a non-silicate mineral, into cement clinker. The industrial residue was used to produce cement clinker. The relationship of the aluminate modulus (IM) and the mineral composition and mechanics of tricalcium silicate-rich sulfur aluminate cement is reported. The effects of the aluminate modulus on the phase compositions, morphology and compressive strength were investigated. The phase morphology was analyzed by optical microscopy. The results show that the increase of IM in the clink can accelerate the formation of calcium sulfoaluminate; calcium sulfoaluminate can form at the temperature of $1250^{\circ} \mathrm{C}$ when the IM value is lower than 2.50, while it exists at a temperature of $1300^{\circ} \mathrm{C}$ without reheating when the IM value is higher than 2.50 .
\end{abstract}

\section{INTRODUCTION}

Ye'elimite $\left(\mathrm{C}_{4} \mathrm{~A}_{3} \$\right)$ is a mineral with rapid hydration, high early strength, small volume shrinkage during hydration and corrosion resistance [1-3]. Hence, a new clinker named alite-ye'elimite clinker was proposed by introducing ye'elimite into Portland cement clinker [4-7]. However, $\mathrm{C}_{4} \mathrm{~A}_{3} \$$ decomposes at $1350^{\circ} \mathrm{C}$, while much $\mathrm{C}_{3} \mathrm{~S}$ begins to form at $1400^{\circ} \mathrm{C}$ [8-12]. To enable the coexistence of alite and ye'elimite, university researchers in Jinan improved the decomposition temperature of ye'elimite by using the ions of $\mathrm{Sr}$ and $\mathrm{Ba}$ to partly replace the $\mathrm{Ca}$ ions. Based on thermodynamic principle, they cannot coexist. The decomposition kinetics of calcium sulfoaluminate have been investigated by Ma Suhua [13]. Shen Xiaodong et al. [14] prepared aliteye'elimite cement clinker by reheating. I. Odler and $\mathrm{H}$. Zhang $[15,16]$ showed that the clinker can be produced at temperatures between $1250 \sim 1300^{\circ} \mathrm{C}$ by adding gypsum and fluorite as mineralizers. Ma Suhua [17] reported that a small amount of metal oxide $\left(\mathrm{MnO}_{2}\right.$, $\mathrm{ZnO}, \mathrm{CuO}$ ) could expand their coexistence range. Also, $0.1 \% \mathrm{MnO}_{2}$ added into the raw meal could improve the decomposition temperature of $\mathrm{C}_{4} \mathrm{~A}_{3} \$$ by $100^{\circ} \mathrm{C}$ and enlarge the coexistence temperature scope between alite and $\mathrm{C}_{4} \mathrm{~A}_{3} \$$ by $57^{\circ} \mathrm{C}$. Upon the addition of $1 \% \mathrm{ZnO}$ to the raw meal, alite is detected in the sample at $1300^{\circ} \mathrm{C}$, as the temperature range of the coexistence of $\mathrm{C}_{4} \mathrm{~A}_{3} \$$ and alite was broadened to $50^{\circ} \mathrm{C}$. The addition of $\mathrm{CuO}(0.1 \%$ in mass) to the raw meal could lower the burn temperature of the clinker, promote the coexistence of $\mathrm{C}_{3} \mathrm{~S}_{\text {and }} \mathrm{C}_{4} \mathrm{~A}_{3} \$$, and increase the strength of the clinker.

Based on the above research, industrial wastes were used as a raw material to make alite-ye'elimite by adding a small amount of metal oxide to decrease the formation temperature of the alite and promote the coexistence of the two phases. In this paper, the influence of IM on the preparation and mechanical properties of the cement made from alite-ye'elimite clinker was investigated, which can be useful for industrial applications.

\section{EXPERIMENTAL}

Raw materials

Limestone, sandstone, copper slag, phosphorus slag, fly-ash and gypsum were used as raw materials. Their chemical compositions are shown in Table 1.

\section{Preparation of the clinker}

The raw materials were ground in a laboratory ball mill to obtain a fineness of $6-8 \%$ over an $80 \mu \mathrm{m}$ sieve. The raw meals were made by mixing these raw 
Hu Y., Ma S., Li W., Shen X.

Table 1. Chemical components of the raw materials measured by X-ray fluorescence (XRF).

\begin{tabular}{lccrrrrrrrrr}
\hline & LOSS & $\mathrm{SiO}_{2}$ & $\mathrm{Al}_{2} \mathrm{O}_{3}$ & $\mathrm{Fe}_{2} \mathrm{O}_{3}$ & $\mathrm{CaO}$ & $\mathrm{MgO}$ & $\mathrm{K}_{2} \mathrm{O}$ & $\mathrm{Na}_{2} \mathrm{O}$ & $\mathrm{P}_{2} \mathrm{O}_{2}$ & $\mathrm{CuO}^{2}$ & $\mathrm{SO}_{3}$ \\
\hline Limestone & 42.24 & 2.63 & 0.83 & 0.44 & 52.16 & 1.46 & 0.08 & 0.01 & - & - & - \\
Sandstone & 1.55 & 86.21 & 5.02 & 5.50 & 0.62 & 0.20 & 0.82 & 0.02 & - & - & - \\
fly-ash & 2.72 & 49.86 & 31.84 & 4.45 & 5.41 & 0.98 & 0.98 & 0.85 & - & - & - \\
copper slag & - & 26.48 & 9.01 & 38.77 & 11.89 & 2.25 & 0.61 & 0.23 & - & 0.25 & - \\
phosphorus slag & - & 39.32 & 4.14 & 0.86 & 48.16 & 1.93 & 0.59 & 0.17 & 1.65 & - & - \\
Gypsum & 20.16 & 13.10 & 4.85 & 1.73 & 23.68 & 2.84 & 0.95 & 0.54 & - & - & 31.47 \\
\hline
\end{tabular}

materials in the laboratory ball mill according to control parameters including a lime saturation factor $(\mathrm{KH})$ of $1.00 \pm 0.02$, silicate modulus $(\mathrm{SM})$ of $2.40 \pm 0.02$ and IM of 1.50, 2.00, 2.50, 3.00 and 3.50. The raw meal was mixed with water and pressed under a pressure of $15 \mathrm{MPa}$ into a disk with $\Phi 40 \mathrm{~mm} \times 25 \mathrm{~mm}$. The dried disks were calcined in a resistance furnace at different temperatures $\left(1250^{\circ} \mathrm{C}, 1300^{\circ} \mathrm{C}, 1350^{\circ} \mathrm{C}, 1400^{\circ} \mathrm{C}, 1450^{\circ} \mathrm{C}\right.$ ) for $60 \mathrm{~min}$, then removed from the furnace immediately and cooled rapidly by a fan to produce clinker. To avoid the effect of the specific area, the specific area was controlled within a set range $\left(360 \pm 18 \mathrm{~m}^{2} \cdot \mathrm{kg}^{-1}\right)$.

\section{Experiment methods}

The content of free lime (f-CaO) was determined chemically after dissolving the clinker in ethanol-glycerin. A thermal analysis was performed on a METTLER TOLEDO 1600LF instrument with a combined TG and DSC system to investigate the physical and chemical changes to the raw meals during the heating. The raw meals were heated from $30^{\circ} \mathrm{C}$ to $1450^{\circ} \mathrm{C}$ with a heating rate of $10^{\circ} \mathrm{C} \cdot \mathrm{min}^{-1}$ under $\mathrm{N}_{2}$ atmosphere. X-ray diffraction (XRD) analysis was used for phase identification and quantification. The XRD patterns was recorded on a Rigaku SmartLab 3000 A diffractometer with $\mathrm{CuK} \alpha$ radiation $(\lambda=0.15406 \mathrm{~nm})$. The $\mathrm{X}$-ray tube was operated at $35 \mathrm{kV}$ and $30 \mathrm{~mA}$. The optics configuration includes a fixed divergence slit $\left(1 / 2^{\circ}\right)$ and a $\mathrm{D} /$ teX Ultra detector. The measurements were collected using $\theta-\theta$ reflection geometry. Data were collected from $10^{\circ}$ to $70^{\circ}$ (clinker) and $5^{\circ}$ to $65^{\circ}$ (the hydration of cement) in the continuous mode. The mineral content of clinkers were be calculated by GSAS (Figure 1a,b).

To investigate the hydration of the clinker produced at temperatures of $1450^{\circ} \mathrm{C}$ and $1300^{\circ} \mathrm{C}$, cement pastes were prepared with water/cement ratios of 0.50 . All hydration experiments were performed at $20^{\circ} \mathrm{C}$.

A conduction calorimeter (Thermometric TAM Air) was used to determine the rate of hydration heat liberation during the first $72 \mathrm{~h}$. A total of $4.00 \mathrm{~g}$ of the cement was weighed into a flask, and the corresponding amount of water was added using a needle. The flask was then capped and placed into the calorimeter until the reading was stable. The mixing was performed by a stirrer for approximately $1 \mathrm{~min}$. Due to the internal mixing, the early thermal response of the samples could be measured.
The total heat of hydration after $72 \mathrm{~h}$ was determined by the integration of the heat flow curve between 0 and $72 \mathrm{~h}$.

The porosity and pore size distribution were measured on fragments of the specimens by mercury intrusion porosimetry (MIP). Samples of both cements, paste hydrated $(\mathrm{w} / \mathrm{c}=0.5)$ and shaped cylindrical discs, were cured for times ranging between $1 \mathrm{~d}$ and $28 \mathrm{~d}$. Before the test, at the end of each aging period, the sample was broken, treated with ethanol to stop the hydration and stored in a desiccator to protect against water and carbon dioxide. For each sample, two plots can be obtained from the porosimetric analysis: (a) cumulative and (b) derivative $\mathrm{Hg}$ intruded volume vs. pore

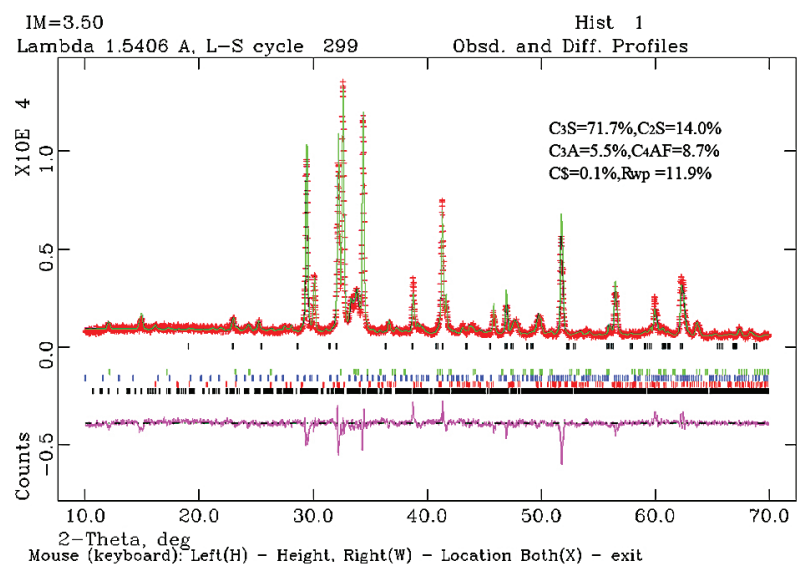

a)

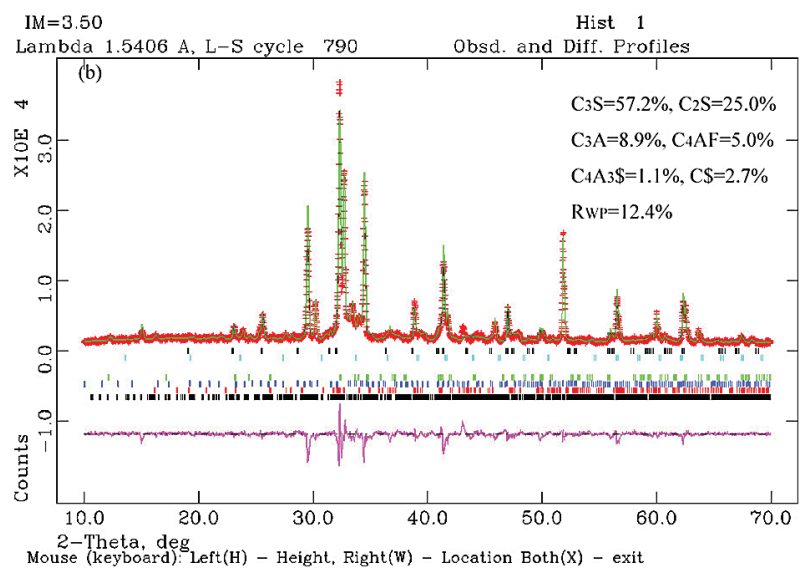

b)

Figure 1. Rietveld refinement of the powder patterns of the clinker used: a) clinker produced at $1450^{\circ} \mathrm{C}$, b) clinker produced at $1300^{\circ} \mathrm{C}$. 
To analyze the phase morphology, optical microscopy (Olympus LEXT OLS 4000) was used. Before that, the clinkers were embedded with epoxy and kept for $1 \mathrm{~d}$; then, the clinkers were polished and etched for $15 \mathrm{~s}$ in a nital solution $\left(1 \mathrm{ml}\right.$ conc. $\mathrm{HNO}_{3}+99 \mathrm{ml} 99.5$ vol. \% ethanol). The compressive strengths of the cement mortars were measured according to EN 196-1.

\section{RESULTS AND DISCUSSION}

The burnability of the cement clinker

The burning of the clinker is reflected by its free lime (f-CaO) content. The $\mathrm{f}-\mathrm{CaO}$ contents are shown in Table 2 for clinkers burned at different temperatures. The IM governs the ratio of the aluminate to ferrite phases in Portland cement, which has important effects on the cement properties, and so determines the quantity of liquid formed at relatively low temperatures. At $1338^{\circ} \mathrm{C}$, the quantity of liquid reaches its minimum at an IM of 1.38 in Portland cement [1]. Table 2 shows that the addition of copper slag and phosphorus slag accelerates the burning of the clinker and promotes the absorption of $\mathrm{f}-\mathrm{CaO}$ at a relatively low temperature $\left(1250-1350^{\circ} \mathrm{C}\right)$ and with the increase of IM, f-CaO can be reduced specially at low temperature although an IM of more than 3.00 has an adverse effect on the burning of the clinker. It is suggested that the IM causes an increase in the liquid viscosity when it is more than 3.00 , although it enhances the amount of liquid. On the other hand, the optimal value of IM decreases with the increase of the burning temperature in this temperature range. At high temperatures $\left(1400-1450^{\circ} \mathrm{C}\right)$, IM has little effect on the burning of the clinker.

Table 2. $\mathrm{f}-\mathrm{CaO}$ content vs. IM and temperature (\%).

\begin{tabular}{lccccc}
\hline & $1450^{\circ} \mathrm{C}$ & $1400^{\circ} \mathrm{C}$ & $1350^{\circ} \mathrm{C}$ & $1300^{\circ} \mathrm{C}$ & $1250^{\circ} \mathrm{C}$ \\
\hline $\mathrm{IM}=1.50$ & 0.05 & 0.06 & 0.09 & 0.36 & 4.49 \\
$\mathrm{IM}=2.00$ & 0.06 & 0.10 & 0.21 & 0.30 & 3.79 \\
$\mathrm{IM}=2.50$ & 0.06 & 0.06 & 0.29 & 0.34 & 3.62 \\
$\mathrm{IM}=3.00$ & 0.03 & 0.03 & 0.29 & 0.41 & 4.73 \\
$\mathrm{IM}=3.50$ & 0.08 & 0.12 & 0.41 & 0.53 & 4.32 \\
\hline
\end{tabular}

Previous research [18] showed that the addition of copper oxide did not reduce the decomposition temperature of calcium carbonate, but it decreased the formation temperature of $\mathrm{C}_{4} \mathrm{AF}$ and promoted the formation of $\mathrm{C}_{3} \mathrm{~S}$ at low temperature. It has been reported [9] that a small amount of $\mathrm{P}_{2} \mathrm{O}_{5}(<1.0 \%)$ could improve the burnability of the raw mix by decreasing the surface tension of the liquid. However, it would inhibit the crystallization of $\mathrm{C}_{3} \mathrm{~S}$ and the preferential formation of the $\mathrm{C}_{2} \mathrm{~S}-\mathrm{P}_{2} \mathrm{O}_{5}$ solid solution when the dosage of $\mathrm{P}_{2} \mathrm{O}_{5}$ exceeds the solubility limit of $\mathrm{P}$ in the $\mathrm{C}_{3} \mathrm{~S}$ phase $(1.1 \%$ $\mathrm{P}_{2} \mathrm{O}_{5}$ ). Sulfur forms an independent liquid in the process of burning. The addition of the copper slag, phosphorus slag and gypsum could improve the burnability of the raw mix. Compared to the sintering temperature of ordinary Portland cement clinker $\left(1450^{\circ} \mathrm{C}\right)$, the sintering temperature is reduced to $1300^{\circ} \mathrm{C}$ for the clinker using copper slag, phosphorus slag and gypsum as raw materials.

\section{Thermal Analysis}

The thermogravimetric results carried out on blends were used to obtain information on the decomposition of chemical compounds during calcination. Figure 2 shows the DSC curves, establishing the decomposition process of the compounds present in the raw material. The first endothermic peak (about $130^{\circ} \mathrm{C}$ ) was attributed to the gypsum in the raw mixtures. The second endothermic peak observed at approximately $782^{\circ} \mathrm{C}$ was proven to be the endothermic decomposition of $\mathrm{CaCO}_{3}$, while the third endothermic peak was proven to be the formation of liquid. As the IM increases, the formation temperature of the liquid increased because of the decreasing of $\mathrm{Fe}_{2} \mathrm{O}_{3}$ amount.

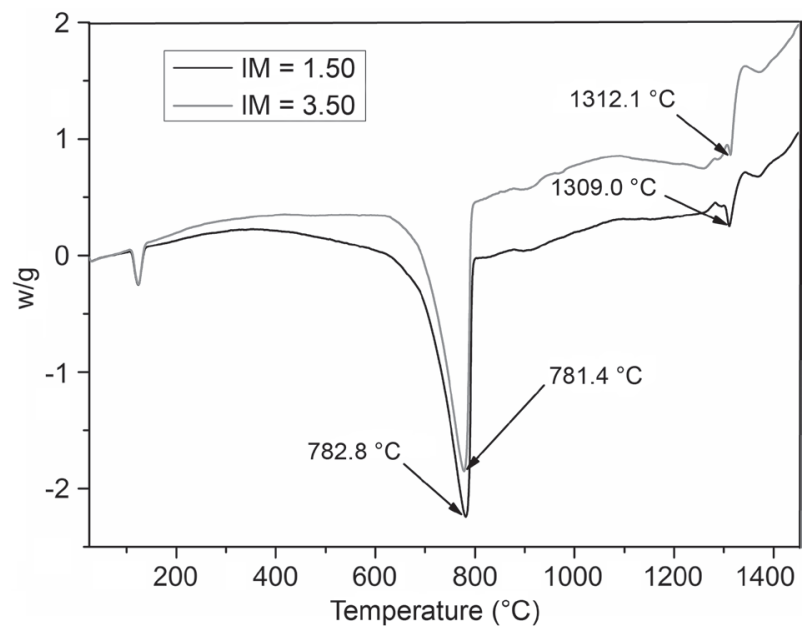

Figure 2. DSC curves obtained from different clinker raw doped with industrial residue, using an atmosphere of $\mathrm{N}_{2}$ and a heating rate of $10^{\circ} \mathrm{C} \cdot \mathrm{min}^{-1}$.

\section{XRD study}

An X-ray diffractometer was used to analyze the phase composition of samples burned at different temperatures $\left(1250,1300,1350,1400\right.$ and $\left.1450^{\circ} \mathrm{C}\right)$. In this paper, the XRD patterns of the samples burned at 1250 , 1300,1350 and $1450^{\circ} \mathrm{C}$ are provided in Figures 3. At $1250^{\circ} \mathrm{C}$, every sample contains six main phases, $\mathrm{C}_{3} \mathrm{~S}(\mathrm{~A})$, $\mathrm{C}_{2} \mathrm{~S}(\mathrm{~B}), \mathrm{C}_{3} \mathrm{~A}(\mathrm{C})$, Ferrite(F), f-CaO(f), $\mathrm{C}_{4} \mathrm{~A}_{3} \$(\mathrm{CA} \$)$ and $\mathrm{CaSO}_{4}(\mathrm{C} \$)$, whose diffraction peaks are shown in Figure $3 a, b, c, d$. The intensity of characteristic diffraction peak $(d=0.375 \mathrm{~nm})$ for $\mathrm{C}_{4} \mathrm{~A}_{3} \$$ was enhanced with the 
increase of IM, while the intensity of characteristic diffraction peaks $(d=0.263 \mathrm{~nm}, \mathrm{~d}=0.348 \mathrm{~nm})$ of the ferrite phase and $\mathrm{CaSO}_{4}$ seem to decrease. In addition, the diffraction peak of the $\mathrm{C}_{3} \mathrm{~A}$ phase is not observed at this temperature. With the ongoing increase of the temperature, the characteristic peak of $\mathrm{C}_{4} \mathrm{~A}_{3} \$$ disappears for the samples with an IM of less than 2.50 due to its decomposition at $1300^{\circ} \mathrm{C}$. At the same time, the characteristic diffraction peak of $\mathrm{C}_{3} \mathrm{~A}$ appears and increases with the increase of IM. When the temperature is more than $1350^{\circ} \mathrm{C}, \mathrm{C}_{4} \mathrm{~A}_{3} \$$ completely disappears, and the phase composition includes $\mathrm{C}_{3} \mathrm{~S}, \mathrm{C}_{2} \mathrm{~S}$, ferrite, $\mathrm{C}_{3} \mathrm{~A}$ and $\mathrm{CaSO}_{4}$ for all of the samples.

\section{Microstructure}

To investigate the phases morphology, pictures taken by light microscopy are shown in Figure 4 for the samples with $\mathrm{IM}=3.50$ at temperatures of $1450^{\circ} \mathrm{C}$

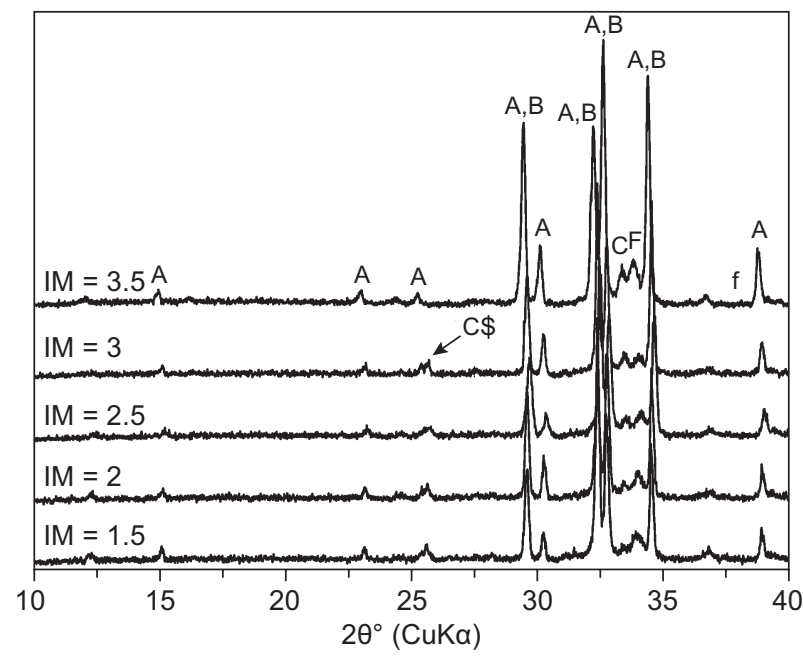

a)

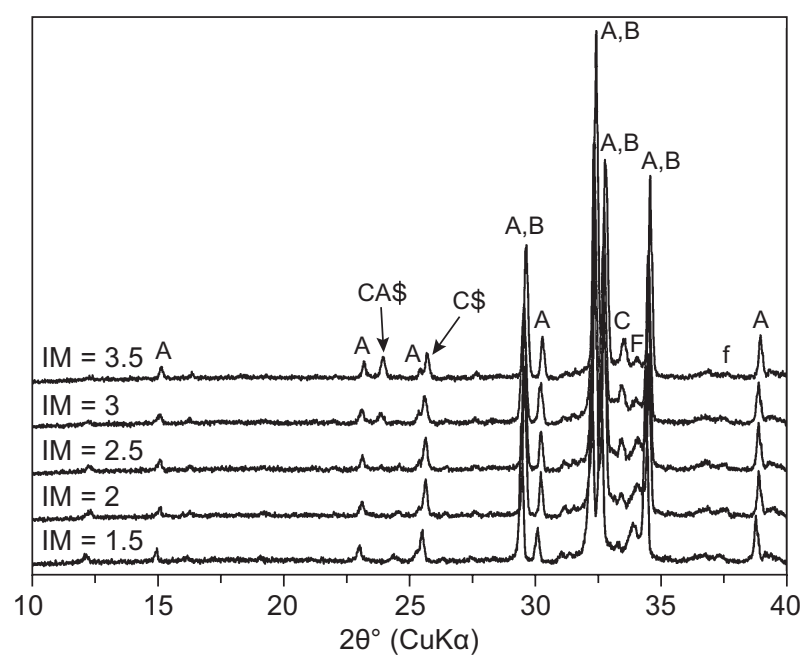

c) and $1300^{\circ} \mathrm{C}$. Crystals of alite and belite are embedded in a matrix of aluminate and ferrite phases. In general, alite crystals are angular, often pseudohexagonal, and belite crystals are rounded and normally striated. In this paper, the alite and belite crystals are blue for samples burned at $1300^{\circ} \mathrm{C}$ due to the use of $1.0 \% \mathrm{HNO}_{3}$ as the etchant. Compared with the DSC analysis, the quantity of the liquid phase was less at this temperature, and the alite does not crystallize well and does not show significant angles. The belite appears rounded, and the alite and belite cluster together. At $1450^{\circ} \mathrm{C}$, alite crystals show a pseudohexagonal structure due to complete crystallization. Their average size is larger than that at $1300^{\circ} \mathrm{C}$. In addition, little belite was found. Most of the silicate phases are alite, which distributes homogeneously in the matrix of the aluminate phase and ferrite phase without clustering. Figure $4 \mathrm{a}$ has a lower porosity than Figure $4 \mathrm{~b}$ because the high temperature causes easy sintering and consequently lowers the porosity.

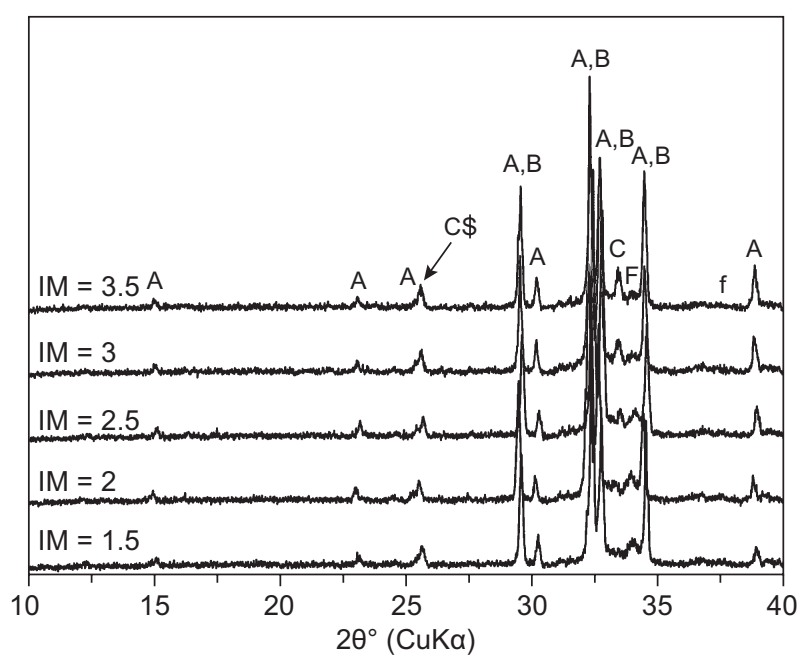

b)

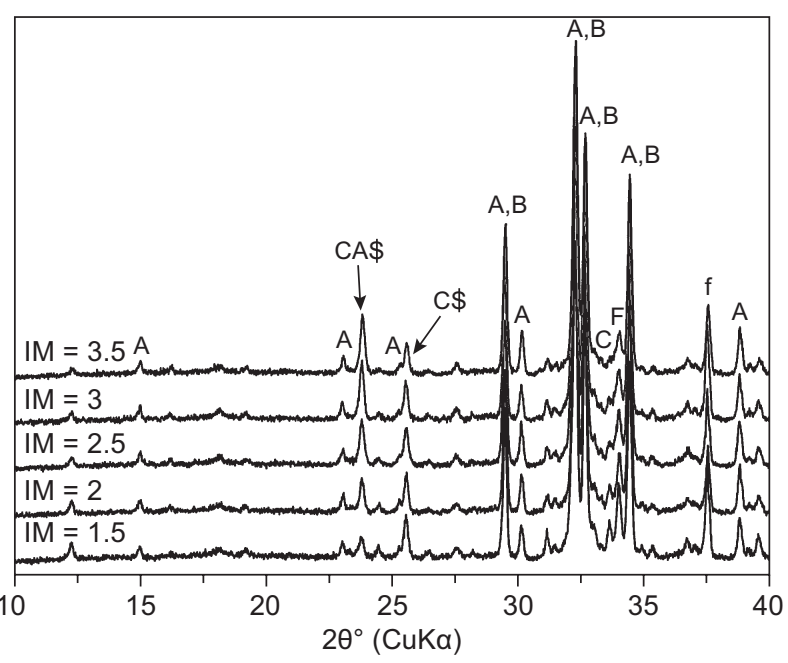

d)

Figure 3. The XRD patterns of the samples burned at $1450^{\circ} \mathrm{C}(\mathrm{a}), 1350^{\circ} \mathrm{C}(\mathrm{b}), 1300^{\circ} \mathrm{C}(\mathrm{c}), 1250^{\circ} \mathrm{C}(\mathrm{d})$. 


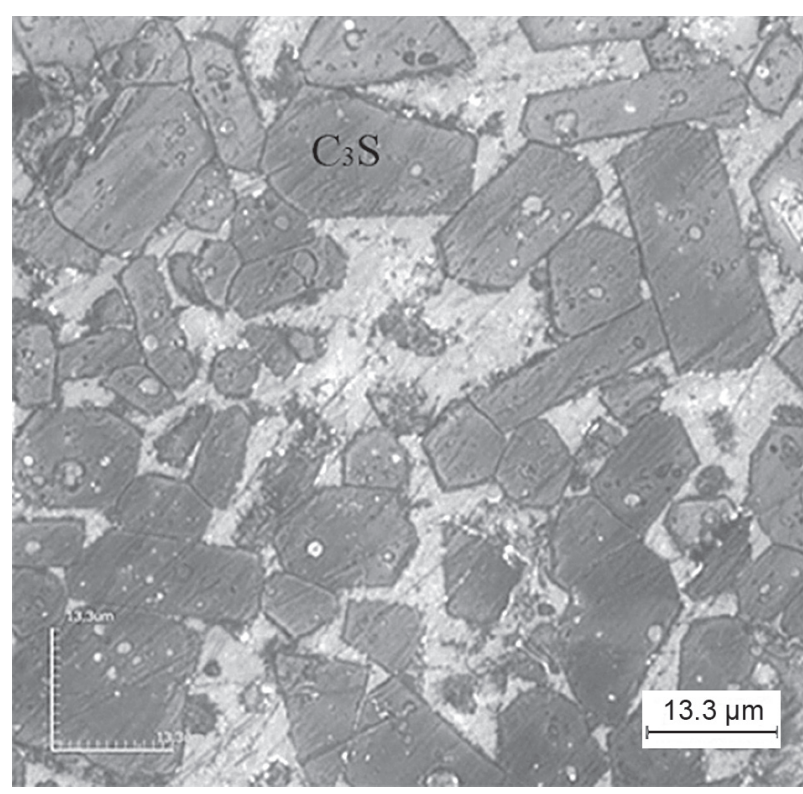

a)

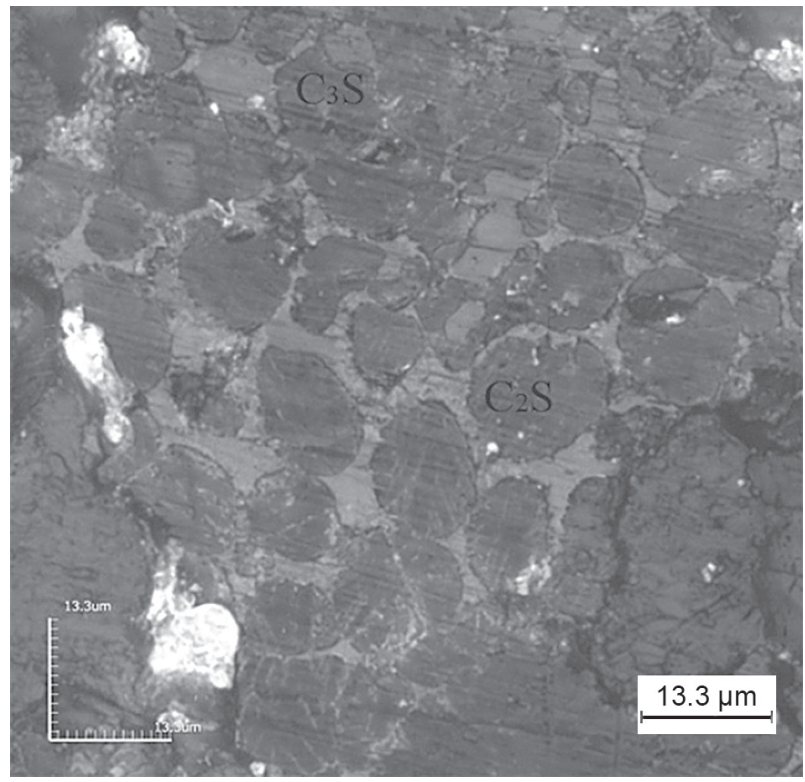

b)

Figure 4. Microscopic view of the clinker heated with $\mathrm{IM}=$ $=3.50$ at the temperatures of $1450^{\circ} \mathrm{C}(\mathrm{a})$ and $1300^{\circ} \mathrm{C}(\mathrm{b})$.

\section{Compressive strength}

The P.II 52.5 cement selected as a reference was provided by a Chinese cement company. It has a typical phase composition including $\mathrm{C}_{3} \mathrm{~S}$ (alite), $\mathrm{C}_{2} \mathrm{~S}$ (belite), $\mathrm{C}_{3} \mathrm{~A}$ (tricalcium aluminate), $\mathrm{C}_{4} \mathrm{AF}$ (tetracalcium ferroaluminates) and some calcite. Two cements were made of two clinkers and gypsum. With the higher quantity of $\mathrm{C}_{4} \mathrm{~A}_{3} \$$, the $\mathrm{IM}=3.5$ is chosen for the two clinkers. However, one clinker is synthesized at $1300^{\circ} \mathrm{C}$ and the other at $1450 \mathrm{C}$. The dosage of gypsum is $5 \%$ by weight of the cement. Their compressive strengths are shown in Figure 5. The compressive strengths of the two cements synthesized are higher at early ages and lower at later ages compared to cement P.II 52.5. $\mathrm{C}_{4} \mathrm{~A}_{3} \$$ has some good properties with early strength and little expansion because its hydration leads to the formation of an initial ettringite (AFt) network and the subsequent infilling by mixtures of ettringite, calcium monosulfoaluminate (AFm) hydrate, alumina and ferrite gels. The XRD results demonstrate that $\mathrm{C}_{4} \mathrm{~A}_{3} \$$ exists in the clinker burned at $1300^{\circ} \mathrm{C}$, apart from $\mathrm{C}_{3} \mathrm{~S}, \mathrm{C}_{2} \mathrm{~S}$, $\mathrm{C}_{3} \mathrm{~A}$ and $\mathrm{C}_{4} \mathrm{AF}$. Hence, the introduction of $\mathrm{C}_{4} \mathrm{~A}_{3} \$$ may cause the increase of the early strength at early ages for the cement burned at $1300^{\circ} \mathrm{C}$. The early compressive strengths were increased by approximately $27 \%$ and $17 \%$, respectively, for the cement burned at $1300^{\circ} \mathrm{C}$. The increase of the early strength may be attributed to the change of phase composition and crystal structure for the cement burned at $1450^{\circ} \mathrm{C}$. In addition, the compressive strength was higher for the cement burned at $1300^{\circ} \mathrm{C}$ compared to that burned at $1450^{\circ} \mathrm{C}$.

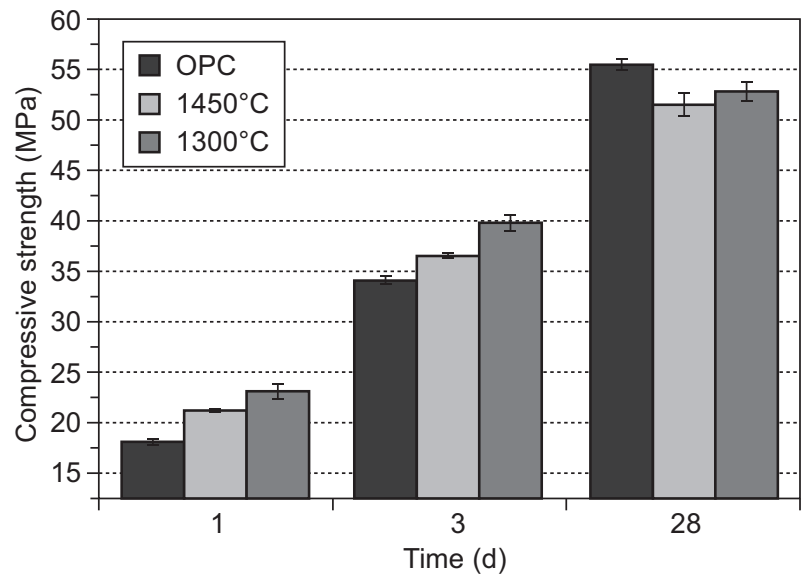

Figure 5. Comparison of the compressive strength of OPC and clinkers burned at different temperatures.

\section{Isothermal calorimetry}

The conduction calorimetry results are shown in Figure 6. Figure $6 \mathrm{a}$ shows that the heat release during the initial period ( 0 to $0.4 \mathrm{~h}$ ) was more quickly for the

Table 3. Chemical composition of P.II 52.5 cement and IM $=3.50$ burning at the temperature of $1450^{\circ} \mathrm{C}$.

\begin{tabular}{lccccccccc}
\hline & $\mathrm{LOS}$ & $\mathrm{CaO}$ & $\mathrm{SiO}_{2}$ & $\mathrm{Al}_{2} \mathrm{O}_{3}$ & $\mathrm{Fe}_{3} \mathrm{O}_{4}$ & $\mathrm{MgO}$ & $\mathrm{SO}_{3}$ & $\mathrm{Na}_{2} \mathrm{O}$ & $\mathrm{K}_{2} \mathrm{O}$ \\
\hline P.II 52.5 & 2.2 & 63.8 & 19.8 & 4.4 & 3.2 & 1.6 & 3.8 & 0.2 & 0.3 \\
$\mathrm{IM}=3.50$ & - & 64.6 & 19.4 & 6.4 & 1.8 & 2.6 & 3.7 & 0.1 & 0.4 \\
\hline
\end{tabular}


clinker produced at temperature of $1450^{\circ} \mathrm{Cthan}$ for the clinker produced at temperature of $1300^{\circ} \mathrm{C}$ due to the minerals of $\mathrm{C}_{3} \mathrm{~A}\left(1450^{\circ} \mathrm{C}\right)$ and $\mathrm{C}_{4} \mathrm{~A}_{3} \$\left(1300^{\circ} \mathrm{C}\right)$ in the clinkers. The first peaks of two clinkers were dissolution peak followed by an induction period, and then a reacceleration of hydration is observed. The second peaks of the curves were attributed to alite hydration. The difference from the clinker produced at the temperature of $1450^{\circ} \mathrm{C}$, the peak three come from the presence of the $\mathrm{C}_{4} \mathrm{~A}_{3} \$$ phase and its reaction with gypsum.

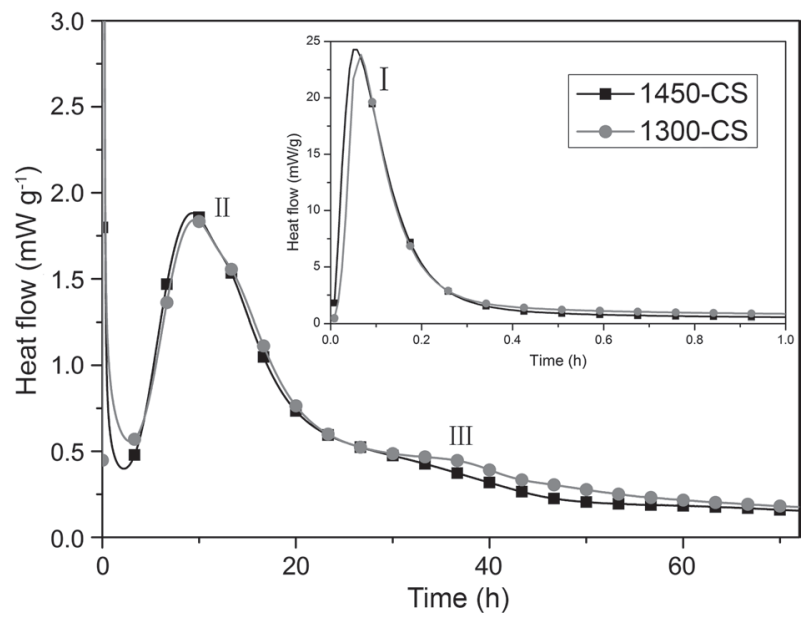

a)

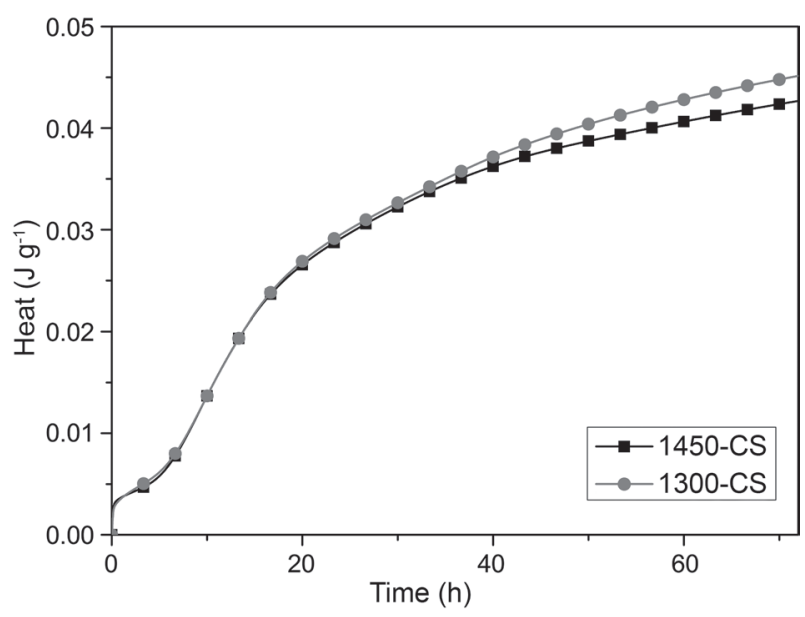

b)

Figure 6. Heat flow development of clinker $(\mathrm{IM}=3.5)$ produced at the different temperatures (a) and cumulative heat, as a function of time, between 0 to $72 \mathrm{~h}$ (b).

Figure $6 \mathrm{~b}$ displays the cumulative heat of hydration that reflects the previous observation: compared to the clinker produced at $1450^{\circ} \mathrm{C}$, more heat of the clinker produced at $1300^{\circ} \mathrm{C}$ was observed.

\section{X-ray diffraction of hydration products}

Figure $7 \mathrm{c}$ shows the hydration of the cement clinker after 1 day. The diffraction patterns of the cement clinkers

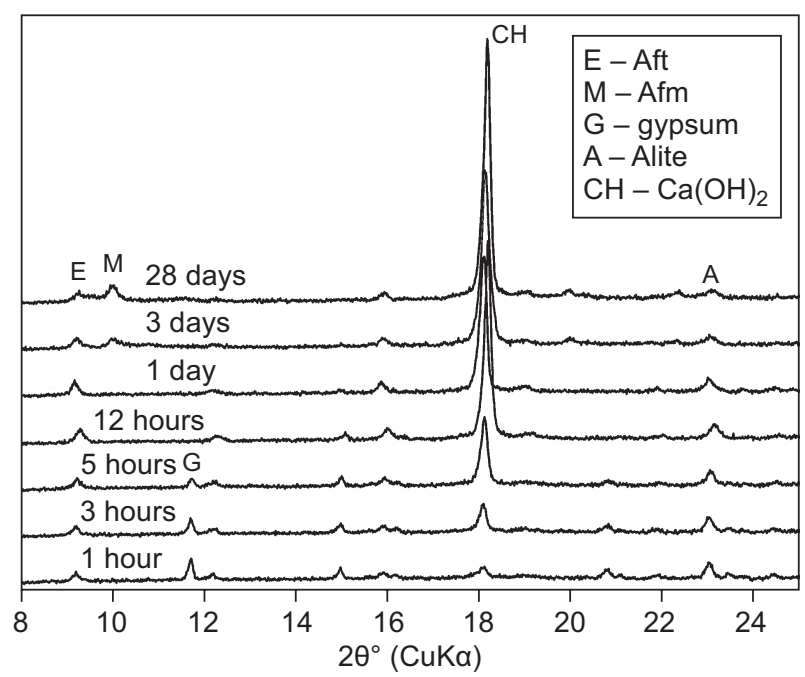

a)

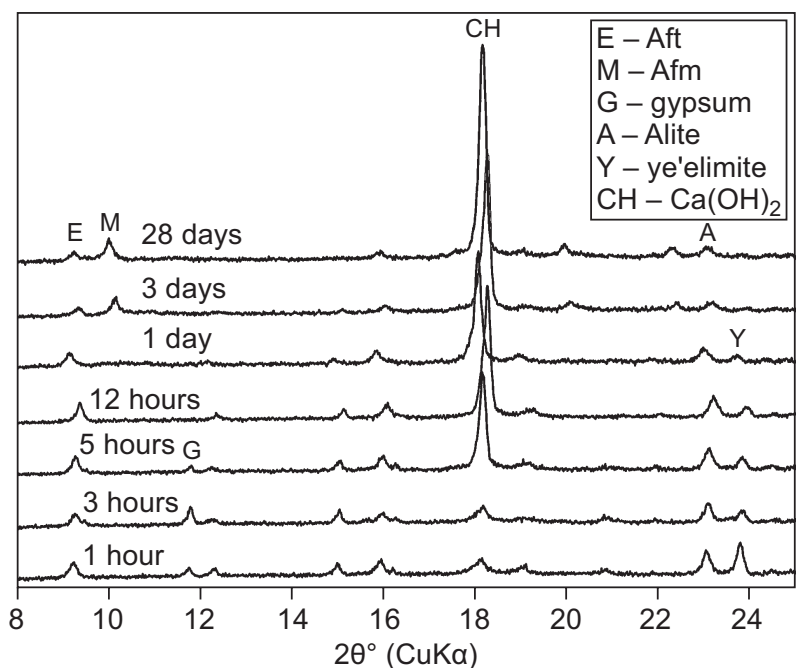

b)

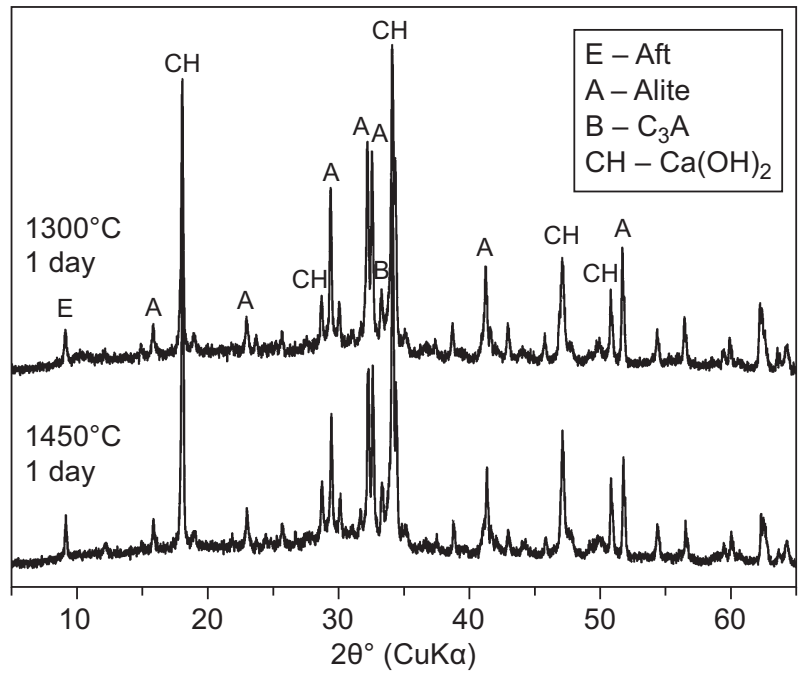

c)

Figure 7. Observed diffraction patterns for hydrated clinker: a) clinker burned at $1450^{\circ} \mathrm{C}$ mixed with $5 \%$ gypsum; b) clinker burned at $1300^{\circ} \mathrm{C}$ mixed with $5 \%$ gypsum; c) hydration of cement clinker after 1 day. 
were similar. The gypsum was consumed completely at $12 \mathrm{~h}$, and AFm was found at 3 day, attributed to the lack of gypsum and the high IM (Figure 7a, b). In the sample with no ye'elimite (Figure 7a), ettringite and portlandite were the main crystalline products found by XRD at the early stages, regardless of the curing method. Over time, AFt phases increased in these samples (at 3, 5, $12 \mathrm{~h}$ and $1 \mathrm{~d}$ ). After 1 day, the ettringite peaks weakened, while the Afm phases (monosulfoaluminate) appeared and became stronger at 28 days. The clinker phases were consumed at different rates, with alite, aluminate and ferrite reacting more quickly than belite. Compared to the sample without the ye'elimite, the hydration rate of the ye'elimite phase was greater than that of the aluminate phase. In one type of behavior, the ye'elimite peaks weaken at $24 \mathrm{~h}$ and ultimately disappear after 3 days (Figure $7 b$ ).

\section{Mercury intrusion}

According to previous research [18-21], mercury intrusion porosimetry plots do not represent the actual distribution of pore size in the hydration of cement. Large internal pores mostly open only to smaller pores communicating with the outside. They do not fill until the higher pressures that are needed for the mercury penetration into the smaller pores are reached. Therefore, almost all of the volume at larger pressures is mistakenly allocated to the size of the smaller ones. Moreover, the measured intrudable porosity does not coincide with the total porosity because, in addition to the pore space actually intruded by mercury, finer pores are present in cement pastes that require a pressure value for entry higher than the maximum available pressure of the commercial instrumentation. A few isolated pores that are entirely sealed against intrusion may exist as well. In this investigation, the pore diameter and the total volume of intruded mercury can be taken as useful indicators of the processes of space filling and pore refinement.

Figure 8 shows the intruded $\mathrm{Hg}$ volume vs. pore diameter for cement pastes cured at various ages. Figure $8 \mathrm{~b}, \mathrm{~d}$ showed that the pore size distribution of the pastes in mortar have the different shape between the clinker produced at the $1450^{\circ} \mathrm{C}$ and $1300^{\circ} \mathrm{C}$. The lower total porosity of the cement paste produced at the $1300^{\circ} \mathrm{C}$ was contributed to the hydration of ye'elimite. The addition of gypsum substantially retarded reaction of the $\mathrm{C}_{3} \mathrm{~A}$, this has been attributed to the protective action of a layer of ettringte. But the gypsum had no effect to the hydration of ye'elimite. The pore size distribution of the cement paste which clinker produced at the $1450^{\circ} \mathrm{C}$ was bimodal, while it was unimodal which clinker produced at the $1300^{\circ} \mathrm{C}$. It was noted that as the pastes cured, the character of the porosimetry curves changed. As the hydration proceeded, the hydration products grew into the pore space of the hardened cement pastes. The initially sharp peak became less dominant, and a second more rounded peak represented the smaller pore sizes. The increase of the curing time resulted in lower total porosity values and smaller threshold pore widths (Figure 8a,c,e). Figure $8 \mathrm{f}$ showed the pore size distribution of the paste had the same shape. The initial peak corresponds to intrusion into a material phase with a distinct network of larger pores, and the roundness of the peak corresponds to a wide distribution of pore size in this material. The pore sizes of the clinker produced at $1450^{\circ} \mathrm{C}$ were larger than that of the clinker burned at $1300^{\circ}$ Cafter 1 day. After 28 days, the pore sizes of the clinker burned at $1450^{\circ} \mathrm{C}$ decreased more quickly than those of the clinker burned at $1300^{\circ} \mathrm{C}$.

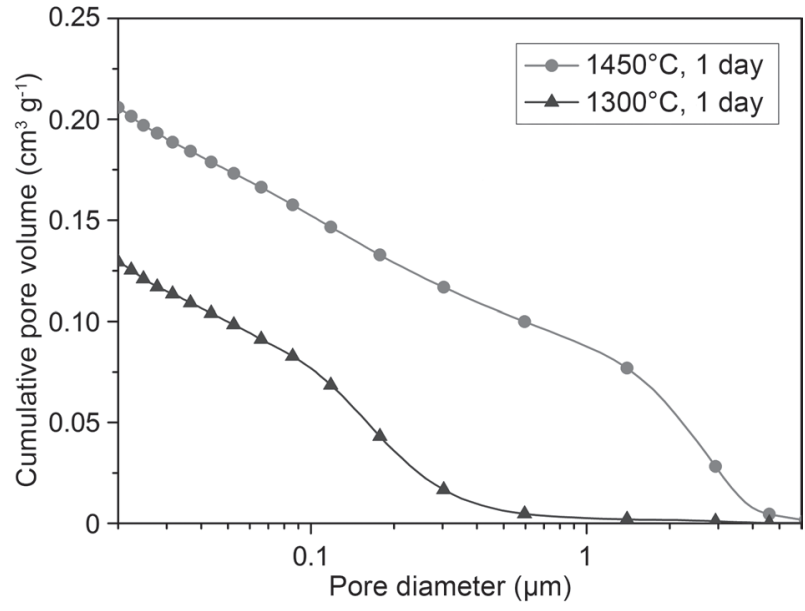

a)

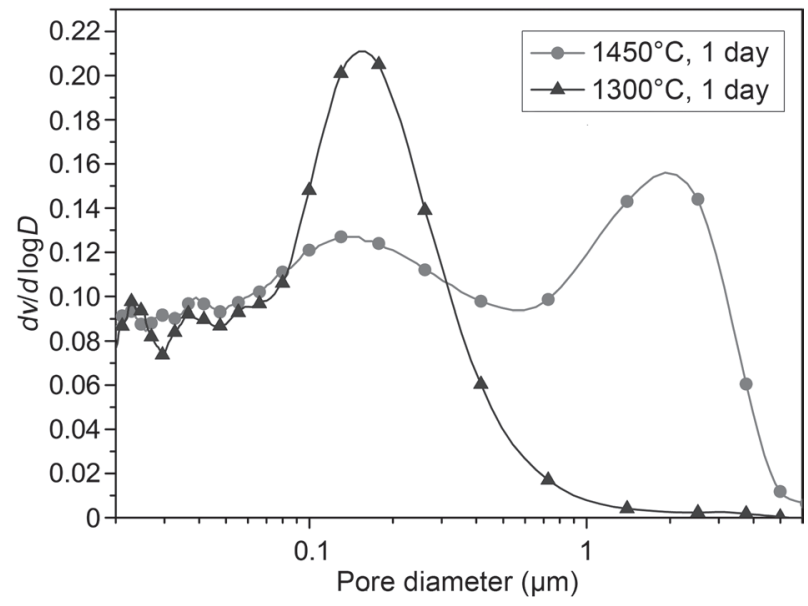

b)

Figure 8. Intruded $\mathrm{Hg}$ volume vs. pore diameter for cement pastes cured at various ages: clinker $(\mathrm{IM}=3.5)$ burned at $1450^{\circ} \mathrm{C}$ and $1300^{\circ} \mathrm{C}$ mixed with $5 \%$ gypsum, cumulative plot $(\mathrm{a}, \mathrm{c}, \mathrm{e})$; clinker $(\mathrm{IM}=3.5)$ burned at $1450^{\circ} \mathrm{C}$ and $1300^{\circ} \mathrm{C}$ mixed with $5 \%$ gypsum, derivative plot (b, d, f). Continue on next page. 


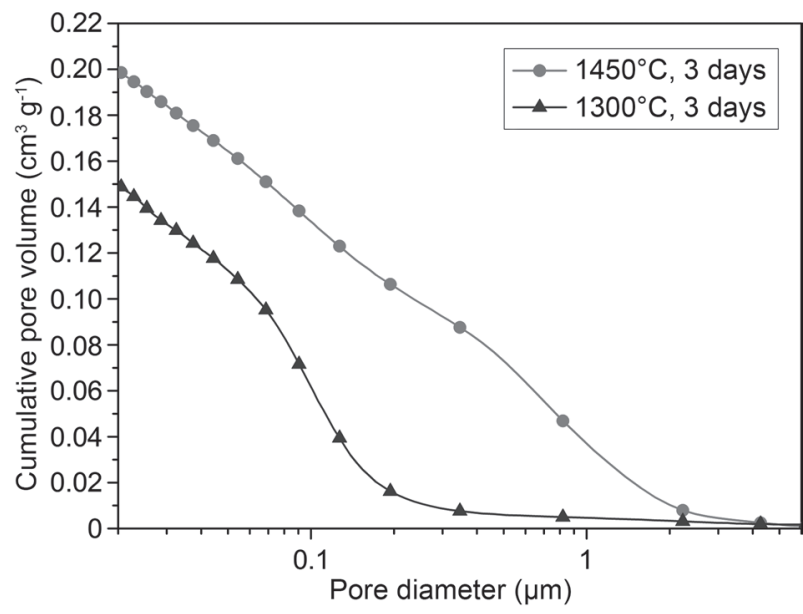

c)

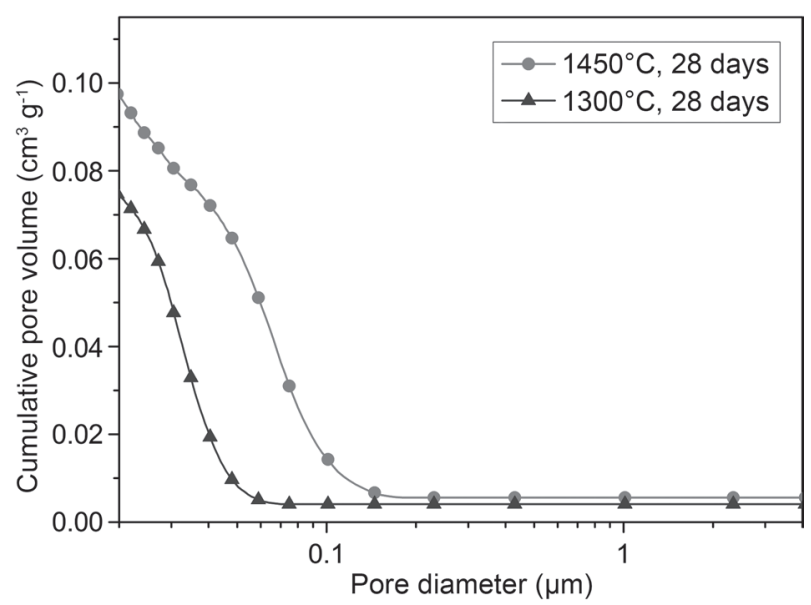

e)

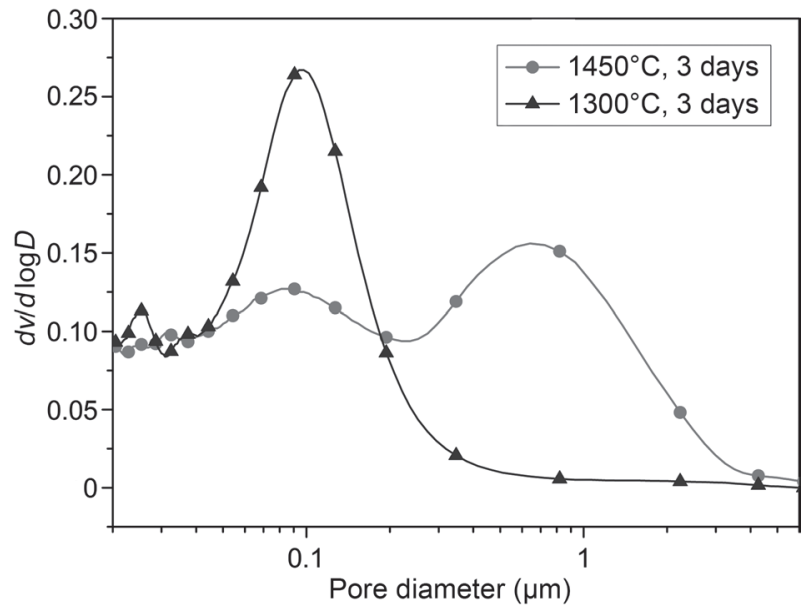

d)

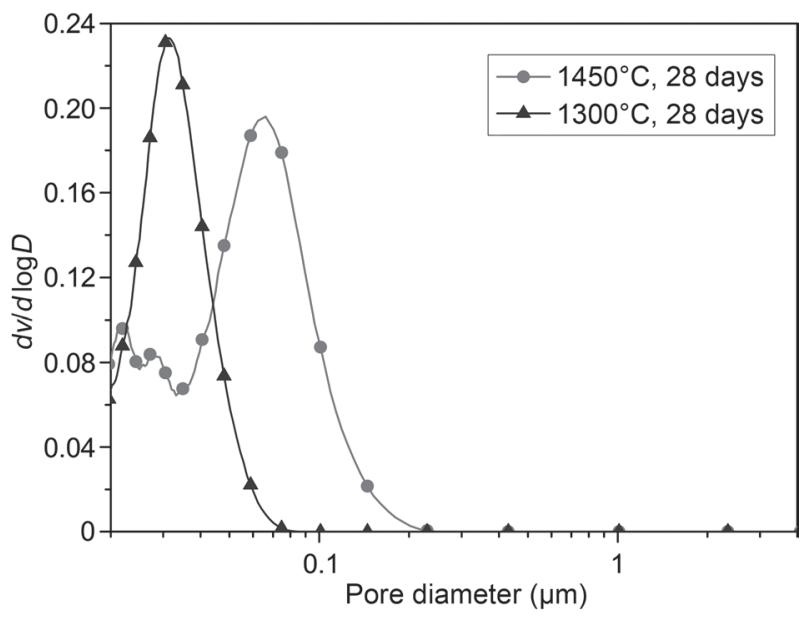

f)

Figure 8. Intruded $\mathrm{Hg}$ volume vs. pore diameter for cement pastes cured at various ages: clinker $(\mathrm{IM}=3.5)$ burned at $1450^{\circ} \mathrm{C}$ and $1300^{\circ} \mathrm{C}$ mixed with $5 \%$ gypsum, cumulative plot $(\mathrm{a}, \mathrm{c}, \mathrm{e})$; clinker $(\mathrm{IM}=3.5)$ burned at $1450^{\circ} \mathrm{C}$ and $1300^{\circ} \mathrm{C}$ mixed with $5 \%$ gypsum, derivative plot (b, d, f).

\section{CONCLUSIONS}

The influence of industrial residue on the phase composition and formation of cement clinker under laboratory conditions was reported in this paper. Industrial residues (copper slag, phosphorus slag) have a distinctly positive effect on the alite crystal nucleation, and they stabilize alite by entering its structure. Ye'elimite formation is blocked by the IM and the temperature. IM changes the viscosity of clinker melt, while the Al content promotes the formation of ye'elimite. When the temperature is higher than $1300^{\circ} \mathrm{C}$, ye'elimite is separated. The hydration rate of the ye'elimite was more rapid. The cumulative $\mathrm{Hg}$ volume and the pore threshold diameter of the alite-ye'elimite clinker decreased little as the curing time progressed from 3 days to 28 days. The compressive strength of the clinker was higher than that of ordinary Portland clinker at 1 and 3 days, but lower at 28 days.

\section{Acknowledgements}

The authors are grateful for the financial support of the National Natural Science Foundation of China (51202109), the national high technology research and development program ("863" program) of China (2015AA034701), the Program for Changjiang Scholars and Innovative Research Team in University (IRT_15R35), Jiangsu National Synergetic Innovation Center for Advanced Materials (SICAM), the National Building Materials Industry Technology Innovation Programme (2015- $\left.M_{3}-2\right)$ and a project funded by the Priority Academic Program Development of Jiangsu Higher Education Institutions(PAPD). The support by the facilities of the Modern Analysis and Testing Centre at Nanjing Tech University, where the detailed microstructural analyses were performed, is also acknowledged 


\section{REFERENCES}

1. Taylor F. W. (1990). Cement Chemistry, $2^{\text {nd }}$ ed. Thomas Telford Publishing, London.

2. Janotka I, Krajèi L È. (2000): Resistance to freezing and thawing of mortar specimens made from sulphoaluminatebelite cement. Bulletin of Materials Science, 23(6), 521527. doi:10.1007/BF02903894

3. Álvarez-Ayuso E., Querol X., Tomás A. (2006): Environmental impact of a coal combustion-desulphurisation plant: Abatement capacity of desulphurisation process and environmental characterisation of combustion byproducts. Chemosphere, 65(11), 2009-2017. doi:10.1016/j. chemosphere.2006.06.070

4. Knox E G. (2008): Atmospheric pollutants and mortalities in English local authority areas. Journal of Epidemiology \& Community Health, 62(5), 442-447. doi:10.1136/jech. 2007.065862

5. Péra J, Ambroise J. (2004): New applications of calcium sulfoaluminate cement. Cement \& Concrete Research, 34(4), 671-676. doi:10.1016/j.cemconres.2003.10.019

6. Zhang L, Glasser F P, Zhang L. (2002): Hydration of calcium sulfoaluminate cement at less than $24 \mathrm{~h}$. Advances in Cement Research, 14(4), 141-155. doi: 10.1680/ adcr.14.4.141.38914

7. Miller F. M., Tang F. J. (1996): The distribution of sulfur in present-day clinkers of variable sulfur content, Cement \& Concrete Research, 26(6), 1821-1829. doi:10.1016/S00088846(96)00171-8

8. Zhang T., Shang S., Yin F., Aishah A., Salmial A., Ooi T.L (2001): Adsorptive Behavior of Surfactants on Surface of Portland Cement. Cement \& Concrete Research, 31(7), 1009-1015. doi:10.1016/S0008-8846(01)00511-7

9. Kolovos K., loutsi P., Tsivilis S., Kakali G. (2001): The effect of foreign ions on the reactivity of the $\mathrm{CaO}-\mathrm{SiO}_{2}-\mathrm{Al}_{2} \mathrm{O}_{3}-$ $\mathrm{Fe}_{2} \mathrm{O}_{3}$ system: Part I. Anions. Cement \& Concrete Research, 31(3), 425-429. doi:10.1016/S0008-8846(00)00461-0

10. Raina K, Janakiraman L K. (1998): Use of mineralizer in black meal process for improved clinkerization and conservation of energy. Cement \& Concrete Research, 28(28), 1093-1099. doi:10.1016/S0008-8846(98)00082-9

11. Tsuboi T., Ito T., Hokinoue Y., Matsuzaki Y. (1972): The effects of $\mathrm{MgO}, \mathrm{SO}_{3}$ and $\mathrm{ZnO}$ on the sintering of Portland cement clinker. Zement-Kalk-Gips, 25, 426-430.

12. Juenger M C G, Winnefeld F, Provis J L, Ideker J.H. (2011):
Advances in alternative cementitious binders. Cement \& Concrete Research, 41(12), 1232-1243. doi:10.1016/j. cemconres.2010.11.012

13. Ma Suhua, Shen Xiaodong, Zhong Baixi (2006): Influence of $\mathrm{CuO}$ on the formation and coexistence of $3 \mathrm{CaO} \cdot \mathrm{SiO}_{2}$ and $3 \mathrm{CaO} \cdot 3 \mathrm{Al}_{2} \mathrm{O}_{3} \cdot \mathrm{CaSO}_{4}$ minerals, Cement \& Concrete Research, 36 (9), 1784-1787. doi:10.1016/j. cemconres.2006.05.030

14. Shen X., Ma S., Li X., Chen L., Zhou W. Deng S. (2013): Secondary synthetic method for calcium sulphoaluminate mineral in Portland cement clinker, US8404039B2.

15. Odler I, Zhang H. (1996): Investigations on high $\mathrm{SO}_{3}$ portland clinkers and cements I. Clinker synthesis and cement preparation. Cement \& Concrete Research, 26(9), 1307-1313. doi:10.1016/0008-8846(96)00128-7

16. Zhang H, Odler I. (1996) Investigations on high $\mathrm{SO}_{3}$ Portland clinkers and cements II. Properties of cements. Cement \& Concrete Research, 26(9), 1315-1324. doi:10.1016/00088846(96)00129-9

17. Ma Suhua, Shen Xiaodong, Huang Yeping, Zhong Baixi. (2008): Preparation and formation mechanism of calcium sulphoaluminate. Journal of the Chinese Ceramic Society, 36(1), 78-81. doi:10.14062/j.issn.0454-5648.2008.01.005

18. Kolovos K, Tsivilis S, Kakali G. (2002): The effect of foreign ions on the reactivity of the $\mathrm{CaO}-\mathrm{SiO}_{2}-\mathrm{Al}_{2} \mathrm{O}_{3}-\mathrm{Fe}_{2} \mathrm{O}_{3}$ system: Part II: Cations. Cement \& Concrete Research, 32(3):463-469. doi:10.1016/S0008-8846(01)00705-0

19. Keith Quillin, Geoff Osborne, Amal Majumdar, Bahadur Singh (2001): Effects of w/c ratio and curing conditions on strength development in BRECEM concretes. Cement \& Concrete Research, 31(4), 627-632. doi:10.1016/S00088846(00)00494-4

20. Ellis Gartner. (2004): Industrially interesting approaches to "low- $\mathrm{CO}_{2}$ " cements. Cement \& Concrete Research, 34(9), 1489-1498. doi: 10.1016/j.cemconres. 2004.01.021

21. Arjunan P, Silsbee M R, Roy D M. (1999): Sulfoaluminatebelite cement from low-calcium fly ash and sulfur-rich and other industrial by-products. Cement \& Concrete Research, 29(8), 1305-1311. doi:10.1016/S0008-8846(99)00072-1

22. Li H, Agrawal D K, Cheng J. (2001): Microwave sintering of sulphoaluminate cement with utility wastes. Cement \& Concrete Research, 31(9), 1257-1261. doi:10.1016/S00088846(01)00579-8 